\title{
ANALISA PENGARUH TINGGI RENDAHNYA TEKANAN MINYAK LUMAS PADA POMPA ELEKTROMOTOR TERHADAP PELUMASAN MESIN INDUK

\author{
Ali Khamdilah $^{1)}$, Djajari ${ }^{2)}$ \\ ${ }^{1), 2)}$ Program studi Teknika Politeknik Bumi Akpelni \\ ali.khamdilah@akpelni.ac.id
}

\begin{abstract}
ABSTRAK
Penelitian ini bertujuan untuk mengetahui dan menanggulangi saat terjadi kerusakan bosh pump dan injector diatas kapal agar dalam pengoperasiannya tidak ada masalah. Beberapa point penting saat akan mengoperasian bosh pump dan injektor dikapal, beberapa tahapan-tahapan yang harus dilakuan untuk menunjang kerja bosh pump dan injector yaitu seperti pengecekan pada bagian-bagian bosh pump dan injector, contohnya pada bosh pump dan injector perlu memperhatikan lebih teliti, karena pada bosh pump dan injector tersebut mudah menimbulkan pengabutan. apabila tahapan tersebut telah dilaksanakan maka pengoperasian bosh pum dan injector dapat dilakukan. Untuk perawatan bosh pump dan injector harus memperhatikan lama kerja bosh pump dan injektor tersebut running hours, apabila telah mencapai maksimal running hours maka kita wajib melaksanakan perawatan, walaupun mungkin belum terjadi kerusakan yang berbahaya. Oleh karena itu perawatan bosh pump dan injector sangat penting sekali agar bosh pump dan injector dapat bekerja dengan baik serta memperpanjang umur bosh pump dan injector tersebut.
\end{abstract}

Kata kunci : injector, pump

\section{Latar Belakang}

Kapal merupakan salah satu sarana transportasi laut yang berperan penting dalam kegiatannya sebagai penghubung antar Negara, wilayah ataupun pulau-pulau. Dalam 
melayani kebutuhan yang semakin meningkat, kapal tidak hanya disediakan dalam jumlah banyak, akan tetapi mengupayakan agar kapal tersebut selalu siap pakai. Pada kapal-kapal yang digerakkan dengan mesin diesel, dalam pemakaian bahan bakar harus dijaga sistemnya. Semua perusahaan pelayaran tidak menghendaki kapal-kapalnya tergabung dalam armada yang tidak beroperasi dengan baik, yang disebabkan oleh tidak berfungsinya salah satu dari komponen mesin, yang mana pernah penulis alami selama proyek laut diatas kapal. Pengoperasian kapal tentunya juga perlu adanya perawatan yang rutin dari motor induk sebagai mesin penggerak utama, agar tidak terjadi delay atau keterlambatan kapal yang disebabkan oleh kurangnya perawatan pada motor induk.

Dalam hal perawatan kapal harus diperhatikan agar kondisi kapal dalam keadaan baik dan aman, terutama dalam perawatan motor induk sebagai mesin penggerak utama. Para masinis yang terlibat dalam perawatan ini menjadi faktor utama dalam pelaksanaannya sehingga pengoperasian kapal dapat berjalan dengan lancar. Salah satu peralatan pada motor induk atau motor diesel yang sangat berguna adalah injector (pengabut bahan bakar), oleh karena itu perlu dihimbau kepada seluruh masinis yang berada di atas kapal agar perlu adanya pemahaman bagaimana cara pencegahan dan penanggulangan pembakaran yang tidak sempurna dari motor induk, baik dari segi teknik perawatan, maupun akibat dari tidak normalnya alat-alat pengabut bahan bakar (injector) tersebut pada motor induk di atas kapal, maka dari itu perawatan injector harus selalu dijaga sehingga mesin induk dapat berjalan dengan baik dan lancar.

Pada dasarnya perawatan injector (pengabut bahan bakar) yang baik adalah melakukan perawatan yang sesuai dengan jam kerja yang telah ditentukan didalam buku manual, dengan demikian dapat meningkatkan efektifitas serta keuntungan 
bagi pemilik- pemilik kapal, karena dengan perawatan injector (pengabut bahan bakar) yang baik dapat menekan biaya opersional kapal, disamping itu juga kondisi mesin itu sendiri.

\section{Pembahasan}

Dari deskripsi data yang disajikan diatas, penulis mencoba menganalisa faktor-faktor yang

menyebabkan perawatan pada injektor pemeriksaan oleh surveyor sebelum dilakukannya proses perawatan . Adapun faktor-faktor itu akan dijelaskan sebagai berikut:

\section{A. Cara Perawatan yang di lakukan untuk merawat Pengabut Injector}

a. Cara perawatan tekanan pengabutan injector :

1. Isikan minyaksolar pada tangki testebar.

2. Pasang pengabut pada tester melalui ujung pipa tekanan tinggi yang ada, dan jangan lupa kokohkan mur nepelnya dengan menggunakan kunci pas,setelah menguatkan mur nidle tekan handle tes untuk membuang udara dalam pipa dan yakni sampai udara dalam injektor tidak ada.

3. Tekan tuas tester agak kuat sampai pengabut menyemprotkan minyak solar,sementara itu sambil diamati tekanan pengabutnya pada manometer menunjukan tekanan kerja dan jarum tidak kebawah terlalu cepat.

4. Jika tekanan terlalu rendah, bukalah mur pengunci pada pengabut dengan menggunakan kunci pas.

5. Kemudian kencangkan baut pengatur tekanan sampai tekanan pengabutnya sesuai dengan tekanan kerja yang telah ditentukan dengan menggunakan obeng min spesial tools.

6. Periksa jumplah devisi semprotan dari lubang injektor dengan menggunakan kertas perhatikan 
gambar pencairan harus semua.

7. Pasang lagi mur pengunc penyetel tekanan baik baik.

8. Lepas pengabut dari tester siap dipasang atau sebagai spare.

b. Fungsi Pengabut Pada Motor Diesel

1. Penyemprotan minyak bahan bakar kedalam ruang bakar (silinder motor diesel)dilaksanakan dengan menggunakan alat yang disebut sebagai pengabut atau injektor. Umumnya pengabut ini dipasang dikepala silinder (cylinder head)motor diesel.Dapat dijelaskan disini bahwa fungsi atau kegunaan pengabut pada motor diesel minyak bahan bakar kedalam ruang bakar sesuai dengan kebutuhan.

2. mengabutkan minyak bahan bakar keruang bakar sesuai dengan derajat pengabutan yang dikehendaki.

3. Mendistribusikan bahan bakar keseluruh ruang bakar sehingga terjadi pembakaran yang merata dan sempurna.

Tekanan udara didalam silinder motor diesel sudah sangat tinggi (kurang lebih 35 Atm ) pada tekanan udara didalam silinder. Kelebihan tekanan ini juga diperlukan untuk memperoleh derajat pengabutan yang sesuai dengan kecepatan penyemprotan (kecepatan minyak solar keluar dari pengabut). Maka makin besar kecepatan penyemprotan makin tinggi derajat pengabutnya. Komponen yang mengatur bentuk. 


\section{B. Kualitas bahanbakar yang kurang baik menyebabkan pembakaran tidak sempurna}

Sistem pembakaran harus selalu baik dan kualitas bahan bakar nya harus selalu tetep di jaga. Cara mengantisipasi agar kualitas bahan bakar tetap baik setiap kapal akan bunker harus di cek terlebih dahulu apakah bahan bakar itu bersih atau mengandung air.Dan sistem pembakaran tersebut sangat penting untuk injector agar pengabutan sempurna atau penyemprotannya agar sangat sempurna. Bahan bakar yang di injeksikan ke dalam ruang pembakaran harus mengalami pengabutan yang memadai guna melakukan pencampuran dengan udara pembakaran sempurna. Mutu bahan bakar yang kurang baik akan mengakibatkan pembakaran tidak sempurna karena campuran partikel bahan dan udara mengandung unsur unsur kimia lain yang tidak dapat terbakar

\section{Kurangnya perhatian dan perawatan masinis terhadap kinerja injector}

Masinis harus selalu memperhatikan dan paham dalam merawat injector karena apabila masinis kurang mengetahui terhadap kinerja injector maka pengabutan injector tidak akan sempurna oleh karena itu masinis harus selalu memperhatikan terhadap kinerja injector dan selalu merawatnya. Apabila injector di rawat dengan rutin maka kwalitas penyemprotan bahan bakar akan di jaga tetap baik.

\section{Pemecahan Masalah}

Langkah-langkah yang diambil untuk alternatif pemecahan masalah dalam hal perawatan injector antara lain :

1. Membuat jadwal perawatanuntuk merawat injector agar perawatan injector berjalan dengan lancar sesuai petunjuk manual book.

2. Meningkatkan ketelitian terhadap perawatan injector dan mengecek kualitas bahan bakarnya 
3. Seorang masinis harus selalu merawat dan memelihara kinerja injector

\section{Evaluasi pemecahan masalah}

Berikut ini beberapa evaluasi pemecahan masalah dari alternati-alternatif pemecahan masalah yang perlu dilakukan antara lain :

1. Meningkatkan ketelitian dalam perawatan injector

2. Keuntungan menggunakan cara ini :

Dengan adanya ketelitian dari KKM dan para perwira khususnya Masinis I, maka proses mempersiapkan perawatanakan dikerjakan dengan sempurna

3 semua kegiatan maintenance disusun dengan program pms ditambah dengan perbaikan - perbaikan dengan emergency kalau ada .Perbaikan dan perawatan dibanyakkan dengan engine team yang solid.

4 Nozzle yang sudah tidak terawat dikapal, sebaiknya dikumpulkan dikapal dan dikirim ke darat, untuk direkondisi dan dites, sehingga jadi spare siap pakai - Hal ini mengambil biaya lebih murah dari pada membeli nozzle baru.

\section{Kesimpulan}

Dari uraian yang telah dibahas maka penulis dapat menyimpulkan sebagai berikut :

1. Perawatan injektor terhadap motor induk yang dilakukan dengan cara mengisikan minyak pada test bar kemudian pasang pengabut pada test bar dan kencangkan mur pengikat dengan menggunakan kunci pas setelah udara dan minyak masuk keluar tutup priming.Tekan tuas testebar sampai klep preming. Hubungkan pipa conection bahan bakar ke nepel masuk injektor kendorkan katup premming tekan tuas tes bar dengan kuat dan perhatikan tekanan manometer atur baut pengatur tekanan sampai tekanan kerja dam perhatikan jarum tidak trun 
cepat menyemprotkan minyak solar,dan amati tekanan pada manometer apabila tekanan terlalu rendah, bukalah mur pengunci pada pengabut dengan menggunakan kunci pas dan kemudian kencangkan baut pengatur tekanan sampai tekanan pengabutnya sesuai dengan tekanan yang telah di tentukan.

2. Perawatan pada injektor sangatlah penting karena apabila injektor kurang perawatan maka injektor tidak bisa mengkabutkan / menyemprotkan dengan sempurna ke ruang bakar / kompresi.

3. Tindakan seorang masinis harus membuat jadwal untuk perawatan injektor sesuai jam kerja yang di tetapkan dan seorang masinis harus melakukan pengecekan bahan bakar minyak pada waktu kapal bunker untuk memastikan bahan bakarnya kotor atau bersih. Dan selain itu masinis di kapal saya, untuk memastikan baik atau tidaknya di ukur dengan alat p.max ( press maximal ) di situlah bisa mengetahui layak tidaknya injektor.

\section{DAFTAR PUSTAKA}

Abdurrahmat Fathoni, 2006, Metodologi Penelitian Dan Teknik Penyusunan Karya Tulis Ilmiah, PT. Rineka Cipta, Jakarta.

House D. J, 1994, Seamanship Techniques single volume edition, Butterworth- Heinemann Ltd, USA.

IstopodanKarlio O.S, 1976, Kapal Dan Perawatannya, Trijaya, Jakarta. Istopo, 1999, Kapal Dan Perawatannya, Koperasi Karyawan BP3IP, Jakarta. Leeming Joseph, 1978, Modern Ship Stowage, Lee Kessinger LCC, Netherland.

Martopo Arso dan Soegiyanto, 2004, Penanganan Muatan, 
Politeknik Ilmu Pelayaran Semarang, Semarang.

Sudjatmiko, F.D.C, 1979, Pokok - pokok Pelayaran Niaga, CV. Akademi Maritim Indonesia, Jakarta.

Thomas R.E, 1983, The Properties And Stowage Of Cargoes, Fergison Brown And Son, England. 